\title{
HUMOR STYLES IN SOCIALLY MALADJUSTED GIRLS AND BOYS: A RESILIENCE PERSPECTIVE
}

\author{
Anna Karłyk-Ćwik ${ }^{1}$
}

\begin{abstract}
Resilience-concept-driven research of humor in socially maladjusted youth has been prompted by an urgent need to redefine Poland's crisis-ridden rehabilitation system, through embracing rehabilitative theories and practices inspired by new frameworks and related modern intervention models. The paper presents a research project aimed at encouraging rehabilitation researchers, theoreticians, and practitioners to engage with humor as a "site of resistance" that offers juveniles a springboard to achieve expected levels of social adjustment. The study aims to identify and compare humor styles in socially maladjusted girls $\left(\mathrm{n}_{1}=56\right)$ and boys $\left(n_{2}=72\right)$. The research problem included the level (intensity) and gender-related differences in particular humor types (styles) across the juvenile sample. The research tool involved an adaption of the Humor Styles Questionnaire (HSQ). The findings suggest a greater intensity of adaptive rather than non-adaptive humor styles in both studied subsets of the sample. Furthermore, a statistically significant gender-related difference was found for self-defeating humor, with significantly higher scores in girls than in boys $(p<0.05)$. Although the findings do not confirm the research hypotheses conclusively, they shed light on the viability of using humor in juvenile rehabilitation and thus, encourage further systematic research in this area.
\end{abstract}

UDC Classification: 376 DOI: http://dx.doi.org/10.12955/cbup.v4.799

Keywords: humor styles, concept of resilience, rehabilitation of juvenile.

\section{Introduction}

The growing engagement of Polish rehabilitative education, with humor, arises from the current demand in rehabilitative practices for new, more effective, context-adequate, and pertinent ways of addressing the needs of socially maladjusted people, as well as the developments in theories of rehabilitation, which increasingly draw on findings of cognitive and humanistic psychology. Robustly developing within the humanistic paradigms, positive psychology provides a new motivation for rehabilitative interventions, in which the priority shifts from elimination of risk factors to promotion of protective factors that are the positive strengths in socially maladjusted people's personalities and external environments.

\section{Theoretical Underpinnings}

Observable over recent years, the dynamic expansion of positive psychology (Seligman \& Csikszentmihalyi, 2000; Snyder \& McCullough, 2000) has brought forth and given wide currency to two concepts of particular relevance to rehabilitative education: resilience and humor styles. The notion of rehabilitative humor intersects the two in the area where interests and investments overlap.

The concept of resilience focuses on explaining how and why some individuals might (or do) achieve positive outcomes, despite unfavorable living conditions and adversities or traumatic experiences or both (Rutter, 1987). This approach draws extensively on Werner's longitudinal research (Werner, 1982; Werner, 2000) from the island of Kauai, as well as Antonovsky's "salutogenesis" (2005). The pioneers of resilience research (Garmezy, 1985; Rutter, 1987; Garmezy, 1991; Werner, 1994) primarily explored individuals coping with adversities, life crises, and trauma in terms of succumbing rather than non-succumbing to disturbances in health and development. Contemporary research and the knowledge it produces about resilience are multidimensional and multifaceted (Rutter, 1993; Kaplan, 1999; Kumpfer, 1999; Luthar, Cicchetti, \& Becker, 2000; Fergus \& Zimmerman, 2005; Ahren, 2006). Definitions of resilience refer principally to that of childhood, adolescence, and early adulthood. They typically list effective functioning in these life stages, mastery of age-adequate skills, and successful performance of developmental tasks, despite reversals of fortune or exposure to strong stress, as well as full recovery of health and rebound from traumatic experiences, in spite of a temporary decline in functioning (Borucka, 2011). In broader terms, resilience has been defined as a dynamic process, comprising cumulative interactions among multiple risk factors, vulnerabilities, and protective factors, which represent the individual's tolerable adjustment, in spite of experienced threats

\footnotetext{
${ }^{1}$ Anna Karłyk-Ćwik, Department of Special Pedagogy, Faculty of Education, University of Lower Silesia in Wrocław, anna.karlyk-cwik@dsw.edu.pl
} 
or traumas. Resilience is understood as a developmental process in and through which children acquire skills instrumental for mobilizing internal and external resources, so as to attain normal adjustment (positive adaptation) despite past or current adversities (Yates, Egeland, \& Sroufe, 2003). Crucially, resilience is neither a permanent individual trait nor a guarantee of extraordinary resistance that can shield individuals against all odds in all situations. Masten and Powell (2003) insist that resilience processes make up a part of regular development of children and adolescents rather than only to children exposed to extremely difficult living conditions or exceptionally adverse fortunes. Hence, resilience may be regarded as a positive or protective process that reduces maladaptation of individuals who experience adversity (Luthar \& Zelazo, 2003).

Proposed by Fergus and Zimmerman (2005), the dual framework of maladjustment risk-reduction (the protective-stabilizing model and the protective-reactive model) is particularly germane to both the synergetic model of social prophylaxis (Urban, 2000) and the rehabilitative group interactions. However, rehabilitation professionals tend to primarily embrace the position advocated by PrinceEmbury (2013, p. 10), who understood resilience as an “... ability to weather adversity or to bounce back from negative experience" and presupposed successful social adaptation, the attainment of the expected social adjustment outcomes, required individuals to experience a critical point from which to "bounce back" and, thus, revert the negative socialization process. Konopczyński (2008) claimed that it entails identifying the juvenile's developmental sphere, which may serve as a "site of resistance," representing a turning point in the process of his or her social functioning. It was assumed that the "site of resistance", which fosters reversal of the maladaptive course of socialization in children and adolescents, may be structured by protective factors of resilience-enhancing processes that fall into three categories: individual or personality attributes, family environment traits, and features of the extra-familial environment, therein school settings and peer groups (Garmezy, 1985; Masten, 2007). In this model, the construct of resilience allows for humor in the rehabilitation space and couples humor with other personal attributes, e.g., optimism, sociability, and serene temperament, as another potentially essential protective factor or a "site of resistance" (or both) that enables socially maladjusted youth to rebound.

The concept of humor styles, developed by Martin, Puhlik-Doris, Larsen, Gray, and Weir (2003), highlights both adaptive and non-adaptive functions of humor and its social relevance. The framework is underpinned by the notion that the role of humor in individual functioning may be adequately grasped by studying, not so much how intense one's sense of humor is, but rather how and to what end one uses humor, and as well, what inter- and intra-personal functions does it fulfil in one's daily life. Consistent with this tenet, humor is considered in two dimensions: its adaptive potential, and its interpersonal and intra-psychic functions in the individual's life that are reflected in the " $2 \times 2$ " model of humor styles (Martin et al., 2003). In this framework, two types of humor, affiliative humor and selfenhancing humor, are deemed instrumental to the individual's effective adaptation outcomes of comfort, wellbeing, and mental health. Two other dimensions, aggressive humor and self- defeating humor, are regarded as harmful and non-adaptive (Martin, 2007, p. 211). Generally, it is assumed that adaptive humor, embodied in self-enhancing humor, is a stress-coping strategy (Lefcourt, Martin, 1986), boosts one's courage in confronting challenges (Mishinsky, 1977; Dixon, 1980), reduces emotional tension, and gives a sense of control and power in the face of risk (Ziv, 1984). Also, this kind of humor improves one's quality of life. Concerning difficult experiences, humor neutralizes traumatic impact by alleviating negative emotions induced by trauma (Lefcourt \& Martin, 1986) and enhancing other positive ones (Kuiper, Martin, \& Dance, 1992), which seem particularly pertinent in the context of resilience. Another form of adaptive humor, i.e., affiliative humor, serves to improve one's relationships with others, while strengthening bonds and minimizing conflicts, and this effectively increases an individual's social attractiveness (Hornowska \& Charytonik, 2011). Thus, in terms of resilience, affiliative humor is an essential protective factor, since it not only reinforces the positive and protective social ties, but also bolsters an individual's self-esteem. Moreover, it generates a positive atmosphere within a group, as it facilitates understanding, reconstructs principles, boosts morale, engenders a sense of group identity, and motivates joint efforts (Ziv, 1984; Lefcourt, 2001; Martin, 2003; Martin et al., 2003). Non-adaptive humor types work in opposite ways. Reliance on non-adaptive forms of humor may lower the sense of self or others' worth. Aggressive humor might be employed to improve one's mood, but at the cost of another's (Zillmann, 1983), and while self- 
defeating humor helps cope with stress inherent of efforts to obtain acceptance by defensive denial, repression of one's feelings, and self-discrediting, it is aimed at gaining and sustaining others' approval at the cost of one's own self-esteem (Kubie, 1971).

Undoubtedly, humor plays an important role in human development and adjustment. Moreover, its adaptive variety is a crucial individual resource and adjustment regulator. As such, it can be considered a "site of resistance", enabling socially maladjusted youth to bounce back, and, consequently, improve their prospects of successful rehabilitation.

\section{Major Methodological Assumptions of Original Research}

Given the theoretical outline above, humor deserves to be given scholarly attention and be thoroughly studied for its role in rehabilitation. For this reason, this research project focuses on humor, and in particular, its four forms: affiliative, self-enhancing, aggressive, and self-defeating, in the context of rehabilitation. The research objective is to identify and compare levels of particular humor styles in girls and boys who have been placed in rehabilitation facilities.

The following research questions were formulated:

1. What is the level of particular humor types in socially maladjusted girls?

2. What is the level of particular humor types in socially maladjusted boys?

3. Are there any statistically significant gender-related differences in the use of particular forms of humor?

The research aimed to test the following working hypotheses:

1. Non-adaptive humor styles prevail in the group of socially maladjusted youth.

This assumption was based on findings reported by founders of the humor styles concept (Martin et al., 2003), who implied that adaptive uses of humor are positively associated with indices of mental health, well-being, and proper adjustment, while non-adaptive humor forms are strongly correlated with indicators of maladjustment, such as hostility, anxiety, depression, low self-esteem, and inability to engage in intimate relationships.

2. There are no clear gender-related differences in the use of adaptive humor forms, while nonadaptive humor styles differ depending on gender.

To date, no pronounced gender-related differences in adaptive forms of humor have been reported in research, but studies have shown that males are more likely than females to display non-adaptive humor behaviors (Martin et al., 2003).

Our research sample included 128 juveniles, who were institutionalized in three Polish Youth Educational Facilities [Młodzieżowy Ośrodek Wychowawczy]. These juveniles were selected by means of the purposive random method. The sample was divided into statistically equinumerous subsets of girls $\left(n_{1}=56\right)$ and boys $\left(n_{2}=72\right)$. As determined by the chi-square test, the two subsets did not differ significantly, with the significance of differences between the subsets at the level of $p=$ 0.157 . The age of respondents in the two subsets was similar, with the mean age of the girls, slightly below 16 years $(M=15.7)$, and boys, slightly above 16 years $(M=16.3)$.

The study was carried out in three Youth Educational Facilities (YEFs) for socially maladjusted children and adolescents aged 13-18, who were placed in pursuant of an order of the Family Court [Sąd Rodzinny]. Applying specialized organization of schooling, intervention methods, education modes, and rehabilitation measures, the YEFs work toward removing causes and symptoms of social maladaptation, preparing the inmates for productive re-engagement with social life, equipping them with occupational tools, and instilling commonly respected social norms and values.

The research relied on the Humor Styles Questionnaire (HSQ) developed by Martin and others (2003) and adapted to the Polish context by Hornowska and Charytonik (2011). The HSQ is a self-description method for expression assessment, in which the respondents define the intensity of behaviors involving humor-based reactions (Hornowska \& Charytonik, 2011, p. 8). The questionnaire contained 32 items that depicted various behaviors linked to the distinguished humor styles and were rated on a seven-point assessment scale ranging from 1 (totally disagree) to 7 (totally agree). The questionnaire included four dimensions, each comprising eight items corresponding to a particular variety of humor. Research has shown that the psychometric parameters of the Polish HSQ version are reliable, 
satisfying, and do not diverge from the analogical parameters of the original tool (Martin et al., 2003; Hornowska \& Charytonik, 2011).

The field research was carried out from October to December, 2015. Subsequently, the collected data were statistically processed using the Shapiro-Wilk test to evaluate the distribution of the variables for normality. In addition, descriptive statistics were calculated (arithmetic means, standard deviations, and variance); a chi-square test was run to establish whether the compared subsets were equinumerous; and the Student's independent two-sample t-test was used to compare the scores for the two subsets. The statistical calculations were performed by means of the PQStat software (v.1.6.2. 64bit).

\section{Results and Discussion}

To define levels of humor styles, a " $1 / 3$ method" was used to establish three brackets of scores, with 8 and 56 as the minimum and maximum values, respectively. The levels (Le) were "low" (L) from 8 to 24.99; "medium" (M) from 25 to 40.99; and high $(\mathrm{H})$ from 41 to 56. Table 1 shows arithmetic means and levels of particular humor styles, together with p-values for the two subsets.

Table 1: The mean levels of humor styles and p-values for gender-related differences (Student's $t$ test)

\begin{tabular}{|c|c|c|c|c|c|c|c|c|c|}
\hline \multirow[t]{3}{*}{ Humor style } & \multicolumn{6}{|c|}{ Gender } & \multirow{3}{*}{$\mathbf{t}$} & \multirow{3}{*}{$\mathbf{p}$} & \multirow{3}{*}{ Significance } \\
\hline & \multicolumn{3}{|c|}{ Female $\left(n_{1}=56\right)$} & \multicolumn{3}{|c|}{ Male $\left(n_{2}=72\right)$} & & & \\
\hline & $\mathbf{M}_{1}$ & SD & Le & $\mathbf{M}_{2}$ & SD & Le & & & \\
\hline Affiliative & 41.04 & 9.07 & $\mathrm{H}$ & 41.32 & 9.01 & $\mathrm{H}$ & 0.174 & 0.862 & Not significant \\
\hline Self-enhancing & 34.29 & 7.95 & $\mathrm{M}$ & 36.14 & 8.03 & $\bar{M}$ & 1.300 & 0.196 & Not significant \\
\hline Aggressive & 28.09 & 8.54 & $\mathrm{M}$ & 28.26 & 7.38 & $\mathrm{M}$ & 0.120 & 0.905 & Not significant \\
\hline Self-defeating & 27.75 & 8.18 & $\mathrm{M}$ & 24.86 & 7.16 & $\mathrm{~L}$ & 2.133 & 0.035 & $\begin{array}{l}\begin{array}{l}\text { Significant for } \mathrm{p} \\
=0.05\end{array}\end{array}$ \\
\hline Source. & & & & & & & & & \\
\hline
\end{tabular}

Table 1 indicates that, in both subsets of the sample, adaptive humor prevails (with no significant differences found between girls and boys). The greatest intensity in both groups was noted in affiliative humor behaviors $\left(\mathrm{M}_{1}=41.04\right.$ and $\left.\mathrm{M}_{2}=41.32\right)$, followed by "I-boosting" (self-enhancing) humor $\left(\mathrm{M}_{1}=34.29\right.$ and $\left.\mathrm{M}_{2}=36.14\right)$ and aggressive humor $\left(\mathrm{M}_{1}=28.09\right.$ and $\left.\mathrm{M}_{2}=28.26\right)$, with selfdefeating humor scoring the lowest $\left(\mathrm{M}_{1}=27.75\right.$ and $\left.\mathrm{M}_{2}=24.86\right)$. The findings failed to confirm the initial assumptions about the prevalence of non-adaptive humor styles in socially maladjusted youth. One explanation may be that the process of adjustment disturbance is not well advanced in these young people thus far, especially with most respondents being first-time inmates of the YEF and placed in this facility due to chronic school non-attendance rather than delinquency or felony. Secondly, the prevalence of adaptive humor forms in the YEF inmates may be a result of the educational and therapeutic interventions launched by the facilities to improve the juveniles' intrapsychic and inter-personal outcomes. Nevertheless, in either case, we could conclude that adaptive humor, which "has endured" in these young people and helps them function despite difficulties and adversities they experience, is a relevant protective factor bolstering the resilience process as "bouncing back from the bottom."

Our findings partly confirmed the second hypothesis about a lack of pronounced gender-related differences in the use of adaptive humor forms and gender-based differentiation of non-adaptive forms of humor. Namely, we found that girls and boys had no statistically significant differences in their use of affiliative and self-enhancing humor; while a statistically significant difference between females and males was evident in the scores for a non-adaptive humor form. Interestingly, unlike most prior studies (Frewen, Brinker, \& Martin, 2008; Greengross, 2008; Charytonik, 2009 in Hornowska \& Charytonik, 2011; Sołomin, 2011 in Hornowska, Charytonik, 2011), this significant difference was unrelated to aggressive humor, but rather it pertained to self-defeating humor, the level (intensity) of which proved significantly higher in the girls' subset than in the boys' $(\mathrm{p}<0.05)$. Up to now, only a few studies have reported significant gender-related differences for aggressive and self-defeating 
humor styles (Kazarin \& Martin, 2004; Cassaretto \& Martinez, 2009; Kazarin, Moghnie, \& Martin, 2010). Martin and colleagues (2003) claimed that self-defeating (as well as aggressive) humor is correlated with anger, hostility, irritability, and aggressiveness. This suggests that the two types of non-adaptive humor have a common denominator, as both seem to serve manipulation and replacement behaviors, which differ in that one is directed against oneself and the other against others (Tomczuk-Wasilewska, 2009, p. 50). Self-defeating (masochistic) humor serves a similar function as self-aggressive behaviors. Eckhardt $(1998$, p. 27) cited American research indicating that $83 \%$ of selfmutilations are by women aged 20-30 who first exhibited self-aggression when aged about 14 , that is, at the beginning of puberty. Patients have reported the experience of emotional deprivation and neglect, beginning in early childhood, because their parents were emotionally withdrawn, with selfcentered mothers treating their children with detachment and indifference (Eckhardt, 1998, p. 64). Similar findings were collected in a study carried out by Fisher and Fisher (1981), implying that standup comedians and classroom clowns, who report the highest levels of masochistic (self-defeating) humor, experienced emotional disturbances in relationships with their mothers, whom they described as less kind, less amiable, reserved, colder, more constrained in contact with the respondents, more self-centered, and controlling than normally expected. The child's bond with the mother is a crucial factor in the process of sexual identification, and consequently, proper mental and social functioning of girls in the puberty period. Hence, various disruptions in this bond are more likely to increase the incidence of diverse self-deprecating and self-aggressive behaviors in girls experiencing pubertyrelated developmental crisis (Eckhardt, 1998, pp. 87-101). This theory offers at least a partial explanation as to why the levels of self-defeating humor are significantly higher in teenage girls than in boys. In young females during puberty, self-defeating humor contributes to releasing tensions, suppressing emotions and needs, repressing negative feelings, and coping with stress arising from attempts at being accepted by the environment (Martin, 2003; Kubie, 1971). In this perspective, selfdefeating humor can be considered as a protective factor that helps one survive a crisis situation.

\section{Conclusion}

While the original research described above failed to support the initial hypotheses conclusively, it succeeded in shedding a new light on humor, and helps address such in the context of juvenile rehabilitation. Particularly, it shows humor as a unique "site of resistance" that enables socially maladjusted youth to rebound and endure through the most challenging moments of life crises. Undoubtedly, our findings will foster further systematic investigation of these issues and future explorations should proceed in three directions: 1) examine the development of humor across the life span of socially maladjusted children and adolescents, as well as the role of humor in their biographies, which would, without doubt, support a more thorough diagnostic; 2) inquire into humor of rehabilitation professionals for humor's impact on the functioning, and personal and professional development of educators, which could render a wealth of valuable pedeutological insights and guidelines; and 3) study the status and applicatory potential of humor in rehabilitation interventions and its impact on their efficacy, which could usefully augment the methodology of rehabilitative influences. In conclusion, it is emphasized that humor undoubtedly carries a huge potential that may offer a new and valuable yearning for rehabilitative theory and practice in Poland.

\section{References}

Ahern, N. R. (2006). Adolescent resilience: An evolutionary concept analysis. Journal of Pediatric Nursing, 21, 175-185. Antonovsky, A. (2005). Rozwikłanie tajemnicy zdrowia. Jak radzić sobie ze stresem i nie zachorować [Unraveling the mystery of health: How people manager stress and stay well]. Warszawa, Polska: Fundacja

[Warsaw, Poland : Foundation] IPN.

Borucka, A. (2011). Koncepcja resilience. Podstawowe założenia i nurty badań [The concept of resilience: Basic research tenets and tendencies]. In W. Junik (Ed.), Resilience. Teoria - badania - praktyka [Resilience: Theory, reserach, practice] (pp. 11-28). Warszawa: Wydawnictwo Edukacyjne Parpamedia [Warsaw: Educational Publishers Parpamedia].

Cassaretto, B. M., \& Martinez, U. P. (2009). Validacion de la Escala del Sentido del Humor en estudiantes universitarios [Validation of Scale Sense of Humor in college students]. Revista de Psicologia [Journal of Psychology], 27(2), 287-309. Dixon, N. F. (1980). Humour: A cognitive alternative to stress? In I. G. Sarason \& C. D. Spielberger (Eds.), Stress and Anxiety (Vol. 7, pp. 281-289). Washington, D. C.: Hemisphere.

Eckhardt, A. (1998). Autoagresja (Self-aggression). Warszawa: Wyd. W. A. B.

Fergus, S., \& Zimmerman, M. A. (2005). Adolescent resilience: A framework for understanding healthy development in the face of risk. Annual Review of Public Health, 26, 399-419. 
Fisher, S., \& Fisher, R. L. (1981). Pretend the world is funny and forever: A psychological analysis of comedians, clowns, and actors. Hillsdale, New York, NY: Erlbaum.

Frewen, P. A., Brinker, J., \& Martin, R. A. (2008). Humor styles and personality vulnerability to depression. Humor, 21(2), 179-195.

Garmezy, N. (1985). Stress-Resistant Children: The Search for Protective Factors. In J. Stevenson (Ed.), Recent Research in Developmental Psychopathology (pp. 213-234). Oxford-New York-Toronto-Sydney-Paris-Frankfurt: Pergamon Press.

Garmezy, N. (1991). Resilience in children's adaptation to negative life events and stressed environments. Pediatric Annals, 20, 459-466.

Greengross, G. (2008). Dissing Oneself versus Dissing Rivals: Effects of Status, Personality, and Sex on the Short-Term and Long-Term Attractiveness of Self-Deprecating and Other-Deprecating Humor. Evolutionary Psychology, 6(3), 393-408. Hornowska, E., \& Charytonik, J. (2011). Polska adaptacja Kwestionariusza Stylów Humoru (HSQ) R. Martina, P. PuhlikDoris, G. Larsena, J. Gray i K. Weir [Polish adaptation of the Humor Styles Questionnaire [HSQ] developed by R. Martin, P. Puhlik-Doris, G. Larsen, J. Gray and K. Weir]. Studia Psychologiczne, 49, 4, 5-22. DOI: 10.2478/v10167-010-0032x

Kaplan, H. B. (1999). Toward an understanding of resilience: A critical review of definitions and models. In M. D. Glanz \& J. L. Johnson (Eds.). Resilience and development: Positive life adaptations (pp.17-78). New York, NY: Kluwer Academic/Plenum Publishers.

Kazarin, S. S., \& Martin, R. A. (2004). Humour Styles, Personality, and Well-Being among Lebanese University Students. European Journal of Personality, 18, 209-219.

Kazarin, S. S., Moghnie, L., Martin, \& R. A. (2010). Perceived Parental Warmth and Rejection in Childhood as Predictors of Humor Styles and Subjective Happiness. Europe's Journal of Psychology, 3, 71-93.

Konopczyński, M. (2008). Współczesne nurty w resocjalizacji [Contemporary trends in rehabilitation]. In B. Urban \& J.M. Stanik (Eds.), Resocjalizacja. Teoria i praktyka pedagogiczna [Rehabilitation: Theory and educational practice] (Vol. 1, pp. 203-212). Warszawa: PWN, WSPR Pedagogium.

Kubie, L. S. (1971). The destructive potential of humor in psychotherapy. American Journal of Psychiatry, 127, 37-42. Kuiper, N. A., Martin, R. A., \& Dance, K. A. (1992). Sense of humor and enhanced quality of life. Personal and Individual Differences, 13, 1273-1283.

Kumpfer, K. (1999). Factors and processes contributing to resilience. The resilience framework. In M. D. Glanz \& J. L. Johnson (Eds.), Resilience and development: Positive life adaptations (pp. 179-224). New York, NY: Kluwer Academic/Plenum Publishers.

Lefcourt, H. M. (2001). Humor: The Psychology of Living Buoyantly. New York, NY: Kluver Academic/Plenum Publishers Lefcourt, H. M., \& Martin R. A. (1986). Humor and Life Stress: Antidote to adversity. New York, NY: Springer Verlag. Luthar, S. S., \& Zelazo, L. (2003). Research on Resilience. An Integrative Review. In S. S. Luthar (Ed.), Resilience and Vulnerability (pp. 510-549), Cambridge: Cambridge University Press

Luthar, S. S., Cicchetti, D., \& Becker, B. (2000). The construct of resilience: A critical evaluation and guidelines for future work. Child Development, 71, 543-562.

Martin, R. A. (2003). Sense of humor. In S. J. Lopez \& C. R. Snyder (Eds.), Positive psychological assessment: A handbook of models and measures (pp. 313-426). Washington, DC: APA.

Martin, R. A. (2007). The psychology of humor: an integrative approach. London, Ontario, Canada: Elsevier Academic Press.

Martin, R. A., Puhlik-Doris, P., Larsen, G., Gray, J., \& Weir, K. (2003). Individual differences in uses of humor and their relation to psychological well-being: Development of the Humor Styles Questionnaire. Journal of Research in Personality, 37(1), 48-75.

Masten, A. S. (2007). Resilience in developing systems: Progress and promise as the fourth wave rises. Development and Psychopathology, 19, 921-930. doi:10.1017/S0954579407000442.

Masten, A. S., \& Powell, J. (2003). Resilience Framework for Research Policy and Practice. In S. S. Luthar (Ed.), Resilience and Vulnerability (pp. 1-28), Cambridge: Cambridge University Press.

Mishinsky, M. (1977). Humor as a "courage mechanism". Israel Annals of Psychiatry and Related Disciplines, 15, 352-363. Prince-Embury, S., \& Saklafoske, D. H. (2013). Resilience in Children, Adolescents, and Adults: Translating Research into Practice. New York, NY: Springer.

Rutter, M. (1987). Psychosocial Resilience and Protective Mechanisms. American Journal of Orthopsychiatry, 57(3), 316 331

Rutter, M. (1993). Resilience: Some conceptual considerations. Journal of Adolescent Health, 14, 626-631.

Seligman, M. E. P., \& Csikszentmihalyi, M. (2000). Positive psychology: An introduction. American Psychologist, 55, 5-14. Snyder, C. R., \& McCullough, M. E. (2000). A positive psychology field of dreams: "If you build it, they will come...". Journal of Social and Clinical Psychology, 19, 151-160.

Tomczuk-Wasilewska, J. (2009). Psychologia humoru [Psychology of humor]. Lublin: Wyd. KUL.

Urban, B. (2000). Zaburzenia w zachowaniu i przestępczość młodzieży [Behavioral disturbances and juvenile crime].

Kraków: Wydawnictwo Uniwersytetu Jagiellońskiego [Krakow : Jagiellonian University].

Werner, E. E. (1994). Overcoming the odds. Developmental and Behavioral Pediatrics, 15, 131-136.

Werner, E. E. (2000). Protective factors and individual resilience. In J. Shonkoff \& S. Meisels (Eds.), Handbook of Early Childhood Intervention (pp. 115-132) (2nd ed.). Cambridge: Cambridge University Press.

Werner, E. E., \& Smith, R. S. (1982). Vulnerable but invincible: A longitudinal study of resilient children and youth. New York, NY: McGraw-Hill. 
Yates, T., Egeland, B., \& Sroufe, A. (2003). Rethinking resilience. A developmental process perspective. In S. S. Luthar (Ed.), Resilience and Vulnerability (pp. 243-259). Cambridge: Cambridge University Press.

Zillmann, D. (1983). Disparagement humor. In P. E. McGhee \& J. H. Goldstein (Eds.), Handbook of humor research (Vol. 1, pp. 85-107). New York, NY: Springer-Verlag.

Ziv, A. (1984). Personality and sense of humor. New York, NY: Springer-Verlag. 